\title{
Dimensions on born-global firms' case studies
}

\author{
Ananda Carvalho Pimenta ${ }^{1 \mathrm{~A}}$, Marcus Joswig ${ }^{\mathrm{B}}$, \\ Moacir de Miranda Oliveira Junior ${ }^{A}$, Roberto Sbragia ${ }^{A}$ \\ AFaculdade de Economia, Administração e Contabilidade- Universidade de São Paulo FEA-USP/SP, São Paulo, SP, Brasil \\ ${ }^{\mathrm{B}}$ Fachbereich Rechts-und Wirtschaftswissenschaften - Technische Universität Darmstadt, \\ FB1/TU Darmstadt, Darmstadt/Hessen, Alemanha
}

ARTICLE DETAILS
Article history:
Received 5 March 2016
Accepted 14 March 2017
Available online in 30 April 2017
Double Blind Review System
Scientific Editor
Ilan Avrichir

\section{Keywords:}

Born-global

Case study

Concepts

\begin{abstract}
The objective of this research is to analyze which dimensions and attributes are discussed in born-global firms' case studies presented by the literature and in practice. For these two specific objectives were proposed: i) identify the dimensions used to study the born-global firms; ii) identify the main concepts applied to such dimensions. Both analyses are based on cases studies addressed in the literature and practical case studies. This research is classified as exploratory and contains a content analysis. Furthermore, it was based on a selection of academic articles obtained on ISI Web of Knowledge database focusing on born-global firms' case studies. The results demonstrate that the main issues regarding the born-global firms are found in an aligned perspective with the theory even when the article is focused on a particular industry. As a contribution, this study presented the list of dimensions and attributes that can be used as a reference for complementary discussions regarding the born-global case studies or even theoretical propositions. The composition of case studies, which provides a broad overview for the researchers, can be considered as an additional contribution of this article.
\end{abstract}

(C) 2017 Internext | ESPM. All rights reserved.

\section{Introdution}

For management in general and strategy in specific, the internationalization theme has evolved prominently. Its conceptual evolution has been supported by the duality of theoretical and practical discussions. In this particular issue, it is understood that the economic-social insertion can be seen as leading in establishing new modus operandi and new perspectives for firms, or as stated by Johanson and Vahlne (1990 p. 22) that firm "internationalization is embedded in an ever-changing world". Furthermore, the authors Jones and Coviello (2005, p.291) presented the following characteristics to distinguish internationalization patterns "(1) mode of transference (cross border business models); (2) place of transference (country); (3) time at which it occurs". Thus, resulting in the research problem of this article: which key aspects are relevant when discussing the internationalization model of bornglobal firms?

Considering this context, this research's overall objective is to analyze which dimensions and attributes are discussed in born-global firms case studies presented by the literature and in practice.

To achieve this objective, the following specific objectives are proposed: i) identify the dimensions used to study the born-global firms; ii) identify the main concepts applied to such dimensions; both analysis are based on cases studies addressed in the literature and practical case study.

\footnotetext{
${ }^{1}$ Author's contact: ananda.pimenta@usp.br
} 


\section{Background}

\subsection{Internationalization}

Johanson and Vahle (1977) started an explicatory approach to the internationalization of companies by creating the so called Uppsala model. Due to the applicability and success of the model, it was constantly updated (JOHANSON; VAHLNE, 1990 and JOHANSON; VAHLNE 2009) and lays the foundation for this research.

The model's first step describes the company's decision in which way they should enter a new market. The entry mode choice should be done by analyzing the costs and risks based on the characteristics of the specific new target market versus its own resources. This process has to be reviewed again after each step of the internationalizing process. With more knowledge of a foreign markets its risks are lowering which again leads to a stronger commitment to the market. This 'Process Theory of Internationalization' describes the company's gradual approaches of entering international markets, which can take up to decades of constantly further involvement

Another influence on the risks related to internationalization is the so called "psychic distance". This attribute is related to the social environment and the gap between the company's experience and knowledge and the market itself. Over time, it was found that it the proximity can, amongst others, be increased by the raise of modern communication technology. According to the researchers, the company's acting in a foreign market allows the firm to increase the knowledge of the market by its gathered experience. This then leads to a greater "commitment" to the market, which can be understood as more investments. With more investment, the learning curve gets steeper which can, in a next step, lead to more investments. The company is step-by-step increasing its foreign activity. However, the exact pathway of each company is very individual and always depends on human decisions. In the review of the model by Johanson and Vahlne in 1990, the authors focus more on the network concept. A company can build its new international relationships by the following three approaches: "(1) Through the establishment of relationships in country networks that are new to the firm, i.e. international extension; (2) through the development of relationships in those networks, i.e. penetration; and (3) through connecting networks in different countries, i.e. international integration." (JOHANSON; VAHLNE, 1990 p. 20)

It is relevant to indicate that the network referred to by the researches is related to the suppliers, customers (e.g. final or sales-channels) and commercial partners. "A firm's success requires that those dimensions are well established" (JOHANSON; VAHLNE, 2009, p.1415). Also, according to Johanson and Vahlne (2009, p.1416), "network knowledge development is more than learning from the agents, but also involves the interaction between a buyer's user knowledge and a seller's producer knowledge which generates new knowledge" for the firm. This widely appreciated Uppsala model describes the process of internationalization itself. However, it does not explain the characteristics that are required or beneficial for the process. These influences can be separated into internal and external attributes.

Internal characteristics that have influence on the company's performance can be summarized under the Resource Based View (RBV), which describes the company as a bundle of "tangible and intangible" (WERNEFELD, 1984, p.172) resources, which are responsible for the "competitive advantage" of a company (TEECE; PISANO; SHUEN, 1997, p.509). Fletcher (2001, p.26) summarizes the most important internal factors found in internationalizing theory as being "(1) management characteristics and (2) organizational characteristics".

Management characteristics include, among others, the international experience accumulated in their life, like time spend overseas or the country of birth. Other characteristics are related to the managers' knowledge like familiarity with the culture and international business practices. Furthermore, planning orientation and having a strategic or proactive approach were considered to be important for successful internationalization.

Organizational characteristics that were considered to be important were the willingness to develop products for oversea markets, to research oversea markets and to fund the international activities. Furthermore, the technological advantage, which is related to the nature of the product was mentioned in the literature.

External incentives can be understood under the industrial organizational theory, which argues that a firm's success depends on its strategy, which is determined by external factors (SCHERER; ROSS, 
1990). The external environment is responsible for the pressures that let a company adapt to the threats and opportunities (COLLIS, 1991). External factors mentioned in the "traditional" internationalization approaches were on one hand related to the aids and incentives of the governments. On the other hand, also domestic as well as oversea demand and competitiveness play an important role in the decision making of the company.

According to the researchers, Oviatt and McDougall (1994b) defined four types of international new ventures, which have an adapted early internationalization strategy. The first dimension is related to the scope of activities of the value chain, distinguishing between few and many internationally coordinated activities of the value chain. The second aspect is the market diversity, which differs between few, and many entered markets. As a result, The framework proposes the following types i) import/export start-ups, ii) multinational traders, iii) geographically focused start-ups and iv) global start-ups. Global start-ups are here defined as companies, which enter various markets and feature an internationalized value chain. In order to address the question when a company is considered to internationalize early, the authors Jones e Coviello (2005) examines further the importance of time to this research stream. They argue that "incorporating time as a primary conceptual dimension is essential to understand entrepreneurial internationalization", due to the fact that "the firm itself and internationalization behavior are also functions of time" (p.290). A company is subject to its passing and it influences the environment. In a way "that the internationalization process is related, directly and cyclically, to numerous performance aspects of the firm performance" (p.299).

To summarize the traditional explanation of internationalization, a traditional firms' internationalization process can be considered as a "stage" model, where firms evolve from sequential stages from selling in the "psychically and geographically close markets" to an ad hoc production site that attends the demand abroad. (KONTINEN; OJALA, 2012 p. 6).

\subsection{Born Global}

The phenomenon of the born-global was first discussed in the business literature over twenty years ago, when in 1993 Mckinsey \& Co. published a study where they identified a group of Australian manufacturers who were exporting just two years after being established. Since then it has gained practitioners and academic attention over the last decades. Its relevance can be recognized by the focus of the book "Globalization and Small and Medium Enterprises" released by OECD - Organization for Economic Co-operation and Development - in 1997 that presented chapters discussing born-global firms.

Born-global firms are in a way challenging the mainstream theories of incremental or gradual internationalization (OVIATT; MCDOUGAL, 1994). Different authors argue that the 'born global' firms' phenomenon contradicts the Uppsala gradual process of internationalization (BELL, 1995) by pointing out that 'born global' firms internationalize rapidly and intensively, almost from their inception.

The born-global concept - according Knight and Cavusgil (2004) - is defined as business firms that, from their founding (or very near of that), seek superior international performance based on the sales originated from multiple countries. To those authors,

"The distinguishing feature of these firms is that their origins are international, as demonstrated by management's global focus and the commitment of specific resources to international activities (...) these early adopters of internationalization begins with a global view of their markets, and develops the capabilities needed to achieve their international goals at or near the firm's founding. (KNIGHT e CAVUSGIL, 2004 p 124, 125).

Looking at the born-global companies from the resource based view, Oviatt and McDougall (2005) summarize the difference between the traditional models and the born-global stream by a shift of the capability's importance. Whereas organizational knowledge is considered crucial in the traditional approaches, born-global firms depend more on the individual managerial knowledge. Some researches indicate, "The internationalization of the born-global firms is driven by entrepreneurial owner managers with a global mindset which allows them to face the market adversities and to seek for opportunities" (WEERAWARDENA ET AL., 2007, p. 299). Especially the creation of networks is of importance for the newly founded companies (FREEMAN; EDWARDS; SCHRODER, 2006). According to Chetty and Campbell-Hunt (2004) the knowledge of the 
entrepreneur can substitute the company's missing experience. The lack of organizational knowledge can even be seen as a facilitator of the rapid internationalization process (AUTIO et al. 2000).

Also, external factors need to be taken into account. Authors like Aspelund and Moen (2005) propose that born-global firms search for international markets as a forced movement to respond to an insufficient domestic market, which can be regarded as constraining the business. Furthermore, external developments are creating an environment that allows new ventures to internationalize rapidly. Examples are the globalization of markets, e.g. international value chains and the homogenization of buyer preferences and technological advances like the information \& communication technologies, international logistics and modern production methods (KNIGHT; CAVUSGIL, 2004).

Although born-global firms have become a prominent area of research, there do not yet exist clear definitions when a start-up, or an early internationalizing company can be considered as born-global. The most prominent characteristics to classify a born global company is firstly the time when the company starts to go abroad and secondly the scale of the foreign operations. Kuvalainen et al. (2012) found in an evaluation of born global definitions that the maximum internationalization time is to be between two and three years. The scale of international activities is, depending on the author, between $25 \%$ and $75 \%$.

One frequent criticism toward the born-global model is based on the fact that the percentage of sales that are supposed to be external might have no relevance depending on the country or even the continent that the company is based in (LUOSTARINEN AND GABRIELSSON, 2006, p.780). Some researches indicate that the internationalization of the "born-global firms is driven by entrepreneurial owner-managers with a global mindset which allows them to face the market adversities and to seek for opportunities" (WEERAWARDENA ET AL., 2007, p. 299). And it is considered that "the internationalization process of born-global firms is a matter of learning through networks" (...) "in a process that is neither planned nor linear". (SHARMA; BLOSTERMO, 2003, p. 750).

According to Tuppura et al. (2008), "born-global firms are supposed to be highly proactive and able to enter new markets rapidly in terms of geographical areas and/or new products and services". (2008 p. 485). Entrepreneurial owner-managers of born global firms assume the "development of innovative products" as a consequence of "close relationship and comprehension to their customer". (MORT; WEERAWARDENA; LIESCH, 2012, p. 556-557).

For Andersson and Wictor (2003) the born-global firms' establishment modes are a strategic choice, which can be the total opposite of traditional models (...) and usually consist of a planned rapid internalization through several modes of entry. In a way, that the strategy is built only based on firms' resources. As stated by Mort, Weerawardena and Liesch (2012, p.551) "the ability to develop and configure innovativeness as marketable products provides a compelling source of competitive advantage and superior performance in born-global firms".

Knight and Cavusgil (2004 p. 124) propose that "future researches should aim at deepening our understanding of early adopters of internationalization, which represent a widespread, ongoing trend." that can be seen across industries and trading countries.

\section{Methodology}

This research is classified as exploratory as it focuses on a better understanding of the born-global internationalization concepts, due to clarification of concepts and ideas (GIL, 2002; GIL, 2008). It takes the form of a literature review since its preparation is achieved using existing papers analysis, like in academic articles (GIL, 2002).

The main advantage of a literature review lies in the fact that, faced as a starting point, the researcher can cover a broad range of his object of study in a much wider way than direct search. This is particularly important when the research problem requires widely dispersed data (GIL, 2008).

The literature review is not limited to repeat or summarize what has already been said about the subject, but its purpose is to reach new approaches and innovative results (MARCONI; LAKATOS 2003). To address the phenomenon of born global companies, publications presenting case studies were taken into account.

Additionally, to the literature review, the authors conducted an interview with a consultant to capture 
the practical perspective regarding born-global companies, in order to assess the alignment between theory development and management practices.

\subsection{Data gathering}

A search was conducted on 06.15.2015 in the ISI Web of Knowledge database and the following filters were applied:

- Title: born global

- Topic: case study

- Search domain (web of science categories): social sciences

- Area research focus (web of science categories): business economics

- Type of publication (document types): article

- Publication language: English

- The search results were applied to a critic review for the relevance of the articles presented based on the citation data presented by ISI.

Articles with no citation (zero) were disqualified from the selection due to the focus on presenting relevant academic discussions.

\subsection{Data analysis}

A content analysis was conducted with the selected articles, to identify the researchers' and scholars' focuses when conducting case studies regarding the born global firms - "considering that the content analysis focuses on identifying the indicators enabling one to deduce that the reality is different from the message" (BARDIN 2011, p. 384).

The content analysis was made considering all the relevant discussions in the following steps: the authors mapped the issues presented within the article, identified similarities in the content, defined the cluster for the similar issues and defined them as an attribute. The attributes were aligned considering the main topics embedded to finally define the dimensions used in the research.

\section{Results}

This section aims to present the results obtained in the research. As described in the methodology, the qualitative analysis conducted in this research was to capture the key dimensions of born-global firms' internationalization discussed in the case studies presented in the selection.

The ISI Web of Knowledge search resulted in 19 articles. These articles had citation numbers between none and over three hundred. After excluding articles with no citation, which guaranteed to present only the relevant discussions in the field, 16 academic articles were chosen for further analysis. After this qualification, the 16 articles were read in order to confirm that the selection was aligned with the purpose of this study (APPENDIXI) and to identify the main dimensions and attributes presented in the born-global firms' case studies.

\subsection{Quantitative Analysis}

In a next step, the analysis was conducted on the selected sample to identify aspects of born-global firms' academic research and the respective issues. Since the main objective of this study is to identify the dimensions presented by the born-global firms' case studies, it can be seen in Chart 1 that oldest publication in the selection was made in 2004.

Even though the first discussion regarding the born-global firm phenomenon was conducted in 1993, the first case study regarding this topic was published eleven years later. Nevertheless, a positive trend of citation numbers can be identified which possibly indicates that the topic is gaining more attention from researches and scholars.

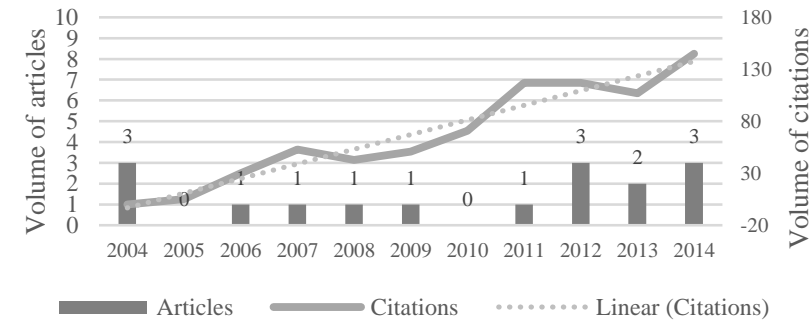

Chart 1.

Total articles per year

Source: elaborated by the authors, based on the research

The Table 1 presents the article frequency by journal, in which can be seen that, within the 10 journals that covered the topic of born-global firms, the academic journals Management International Review (focus on research in the fields of international management) and International Marketing Review had the greatest number of relevant articles. 
Tab. 1

Article frequency by journal

\begin{tabular}{lcc}
\hline Journal & Frequency & Percentage \\
\hline $\begin{array}{l}\text { Management International } \\
\text { Review }\end{array}$ & 3 & $18,75 \%$ \\
\hline International Marketing Review & 3 & $18,75 \%$ \\
\hline International Business Review & 2 & $12,50 \%$ \\
\hline $\begin{array}{l}\text { Journal of International } \\
\text { Marketing }\end{array}$ & 2 & $12,50 \%$ \\
\hline $\begin{array}{l}\text { European Journal of Marketing } \\
\text { Industrial Marketing }\end{array}$ & 1 & $6,25 \%$ \\
Management & 1 & $6,25 \%$ \\
\hline $\begin{array}{l}\text { International Small Business } \\
\text { Journal }\end{array}$ & 1 & $6,25 \%$ \\
\hline $\begin{array}{l}\text { Journal of International } \\
\text { Business Studies }\end{array}$ & 1 & $6,25 \%$ \\
\hline $\begin{array}{l}\text { Journal of The Asia Pacific } \\
\text { Economy }\end{array}$ & 1 & $6,25 \%$ \\
\hline Long Range Planning & 1 & $6,25 \%$ \\
\hline & & \\
\hline
\end{tabular}

Source: elaborated by the authors, based on the research

\subsection{Qualitative Analysis}

The Table 2 presents the dimensions and attributes identified in on the selected articles - the complete list of attributes identified by the researches is presented at APPENDIX II. In this table, it can be seen that although the total number of internal and external factors are equal, the attributes do not replicate the proportionality (14 articles present the same number of citations for Internal and External factors). The most frequently mentioned attributes for internal factors are "entrepreneurs or manager knowledge" indicating the owners' and managers' relevance for the process of internationalization of a born-global firm. When considering the External Factors, both attributes "market development abroad" and "partnership and networking" present the same high frequency, what can possible indicate the foreign market perspectives are extremely correlated to the network and the partnership built in the new market.

Considering that the selection contains only empirical articles that aim to discuss and test hypothesis regarding one or more born-global firm concepts, it was observed that the perspectives captured by the case-studies, although plural, present concepts that are aligned with a global perspective of born-global firm model.

Tab. 2

Attributes' frequency

\begin{tabular}{llc}
\hline Dimensions & Attributes & Frequency \\
\hline $\begin{array}{llc}\text { Internal } \\
\text { Factors }\end{array}$ & 14 \\
\hline & Entrepreneurs or Manager & 12 \\
& Knowledge & \\
& Firm Strategic Focus & 5 \\
\hline External & Firms' Innovative Capacity & 9 \\
Factors & & 14 \\
\hline & Domestic Market Growth & 7 \\
\hline & Market Development (abroad) & 10 \\
\hline & Partnership and Networking & 10 \\
\hline
\end{tabular}

Source: elaborated by the authors, based on the research

When considering the internal factors, the selected articles have the following propositions:Entrepreneurs or Manager Knowledge

- The born-global theorists Chetty and Campbell-Hunt (2004) found that the "entrepreneurs are accustomed to operate in a global economy. This characteristic is strengthened by the advance of communication technologies. Those attributes are then used to develop strategies and maintain the relationships required by an accelerated process of internationalization". (2004, p.62)

- Born-global firms usually are founded by entrepreneurs with a "strong international perspective". They usually have a strong customer focus with high quality products. Furthermore, they heavily use the firm's "marketing competence" in order to be successful outside of their home market. (KNIGHT; MADSEN; SERVAIS, 2004 p. 647)

- For Knight and Cavusgil (2004) "the international entrepreneurial orientation of bornglobal firms reflects a managerial mindset focused on innovation that leads the firm to pursue strategies aimed to maximize international performance". (2004, p.136)

Firm strategic focus

- According to the authors Chetty and CampbellHunt (2004) due to the fact that "focus and pace of 
internationalization are established by competitive imperatives to seize a leading position in niche or emerging markets", it's necessary "to emphasize the role of strategy in the internationalization process" (2004, p.63).

- Kalinic and Forza (2012) indicated that bornglobal firms have "extreme flexibility" and are able to "adapt ever-changing external conditions". (2012, p.697)

- "Born-global firms demonstrated a highlydeveloped ability to identify and mobilize resources from external sources, enrich and extend existing internal resources and to recombine these in novel and elaborated ways with a strategic purpose". (MORT; WEERAWARDENA; LIESCH, 2012 p. 552)

Firms' innovative capacity

- "Knowledge that fosters unique products development also allows born-global firms to serve specific markets well, giving rise to increased market share and sales growth and supports superior international performance". (KNIGHT; CAVUSGIL, 2004, p. 131)

- For the authors Knight, Madsen and Servais (2004) "the strategy elements of product quality, marketing competence and product differentiation are a direct influence to born-global organizational performance". (2004, p. 654)

- Frequently, according to Trudgen and Freeman (2014), born-globals "operate in specialized markets in highly technical industries with their innovative products in a way that financial returns can be delayed as a scenario of the time and resources needed to educate the market about the value of their products". (2014, p. 570)

Considering the external factors, the case studies mentioned the following characteristics to be beneficial for the creation of born-global firms:

Domestic market

- "Born-global founders perceive the world as one market and thus do not confine themselves to a single country", this happens due to the fact that "they recognize the limited importance of the domestic market from the firms' inception", mainly because "they may have either a small domestic market or no domestic market". (CHETTY; CAMPBELL-HUNT, 2004 p. 61)
- For Freeman; Hutchings; Chetty (2012) bornglobal firms potentially perceive the "downturns of the home market as a trigger to seek foreign locations that can be used to offset fluctuations in demand, as much as changes in the home market regulatory environment". (2012, p.441)

- "The pace of born global firm internationalization occurred because of the entrepreneurial drive and interpretation of the founder(s) as well as the small size of the domestic market" (p.704) and its "maturity". (p.706) (TAYLOR; JACK, 2013)

\section{Market development (abroad)}

- Born-global firms "followed international market changes and competitors' actions and then developed their responses, acting like a market driven firm due to product characteristics in the industry". (KOCAK; ABIMBOLA, 2009) p. 447)

- Born-global firms' effective institutional bridging starts with "developing detailed social and cultural knowledge about the target markets, such as (1) knowledge about potential customers to customize products and services; (2) cultural knowledge about the norms and practices that underpin commercial transactions, and (3) knowledge of the legal and regulatory environment, both formal and informal". (KARRA; PHILLIPS; TRACEY, 2008, p.448)

- The born-global firm's most developed resources are the "capability to create new markets, generate demand and position itself as a leader in those markets". This ability is further strengthened by the "strong capacity to innovate and consequently be a first-mover in the markets". (SEPULVEDA; GABRIELSSON, 2013, p. 799)

- For Trudgen; Freeman, (2014, p.571) the bornglobal firms are "aware (...) of the challenges of psychic distance", which "reflects a longer-term business perspective, prolonging the amount of time born-global spent in the early international entry/ development phases".

Partnership and networking

- For "born-global firms, the influence of networking capability is not restricted to impact on capital requirements and management skills but is instrumental in developing innovative products, in locating markets across national borders and in 
international market performance" (MORT; WEERAWARDENA, 2006, p.568)

- Born-global "strategies that utilize partners are favored because they enabled partnership advantages providing market access and end customer credibility". (GABRIELSSON; GABRIELSSON, 2011, p.97)

- For Hagen and Zucchella (2014) "the bornglobal firms' social networks work as an accelerator" (p.519) and "a significant proportion of the opportunity for exploration and exploitation is to be found by born-global firms in partnerships, which represent a key asset in this companies' resource base". (p. 523)

To strengthen the critical view regarding the bornglobal firms' dimensions and attributes, the authors discussed the born-global firms' model with a practitioner who supports firms in their early stages of the internationalization process. This should be regarded as a validation of the case studies (APPENDIX III). This additional case - considered exploratory by the authors, "offered the opportunity to explore the limits of the descriptions and explanations developed" in the article selection's cases (SWANBORN, 2010, p. 105)

The main aspects brought by the consultant regarding the born-global firms were (i) the internationalization requires profound knowledge and preparation about the target market, (ii) the decision of becoming a born-global firm usually considers the external factors as much as the internal factors in a combined view, (iii) the entrepreneurs understand that it is crucial to establish a local infrastructure / relationship (clients, suppliers, distributors, investors), (iv) the internationalization adoption is aligned with the firm strategic focus, (v) the born-global firms' entrepreneurs are relevant to the internationalization model and have some distinct characteristics (understanding the foreign market, for example) and (vi) born-global firms are resource-constrained firms in the beginning of the internationalization process.

\section{Conclusion}

This research's overall objective was to analyze the dimensions and attributes discussed in bornglobal firms' case studies, in order to extend the understanding of this phenomenon. To achieve this objective two questions were answered: i) identify the dimensions used to study the born-global firms; ii) identify the main concepts applied to such dimensions; both analyses are based on cases studies addressed in the literature and practical case studies.

To properly conduct this research, a categorization was proposed that allowed the authors to map the issues in a standard approach. As a result, the main issues presented in the sample were clustered in one of the six attributes that were consolidated into two dimensions.

The results demonstrated that the main issues regarding the born-global firms are developed in perspective that is aligned to the literature and to the management practice experienced by consulting firms. The authors considered the distinct relevance presented by the attributes used in the research that in a way captures the main perspectives/agents that support the born-global firm internationalization. Furthermore, the authors understood that this alignment occurs as a result of the following context: (i) the born-global firm model has not reached a mature phase; (ii) the plurality of the issues derive from the fact that the case studies are built to analyze different purposes in multiple industries.

As a contribution, this study presented a list of dimensions and attributes that can be used as a reference for further discussions regarding the bornglobal firms' case studies or even theoretical propositions. The composition of case studies can be considered as an additional contribution developed by the authors by providing a broad overview for the researchers.

The study's limitations can be considered to be the rather low number of selected articles that might have some influence on the dimensions and attributes proposed.

\section{References}

- ANDERSSON, S., WICTOR, I. (2003) Innovative internationalism in new firms: born globals - the Swedish case, Journal of International Entrepreneurship, 1, 249-276

- ASPElund, A., MOEN, O. (2005) Small international firms: typology, performance and implications, Management International Review, Vol. 45 No. 3, pp. 37-50.

- AUTIO, E., SAPIENZA, H.J., ALMEIDA, J.G., 2000. Effects of age at entry, knowledge intensity, and imitability on international growth. Academy of Management Journal.

- BARDIN, L. Análise de Conteúdo. Lisboa: Edições 70, 2011 
- BELL, J. (1995) The internationalization of small computer software firms, European Journal of Marketing, Vol. 29 Iss 8 pp. $60-75$

- CHETTY, S. AND CAMPBELL-HUNT, C. (2004) A strategic approach to internationalization: a traditional vs a "BornGlobal" approach, Journal of International Marketing, Vol. 12, No. 1, pp. 57-81.

- COLLIS, D.J. (1991), A resource-based analysis of global competition: the case of the bearings industry, Strategic Management Journal, Vol. 12, pp. 49-68.

- Fletcher, R. (2001). A holistic approach to internationalisation, International Business Review, Vol. 10, No. 1, pp. 25-49.

- freeman, S., edWARds, R., SChroder, B. (2006). How smaller born-global firms use networks and alliances to overcome constraints to rapid internationalization. Journal of International Marketing, Vol. 14, pp. 33-63

- FREEMAN, S; HUTCHINGS, K; CHETTY, S. Born-Globals and Culturally Proximate Markets. Management International Review. 2012

- GABRIELSSON, M; GABRIELSSON, P. Internet-based sales channel strategies of born global firms. International business review, 2011

- GIL, A. C. Como elaborar projetos de pesquisa. 4. ed. São Paulo: Atlas, 2002

- GIL, A. C. Métodos e técnicas de pesquisa social. 6. ed. - São Paulo: Atlas, 2008.

- HAGEN, B.; ZUCCHELLA, A. Born Global or Born to Run? The Long-Term Growth of Born Global Firms. Management International Review,. 2014

- JOHANSON, J. \& VAHLNE, J.-E. (1977) The internationalization process of the firm: A model of knowledge development and increasing foreign market commitments. Journal of International Business Studies, Vol. 8, No. 1, pp. 23-32.

- JOHANSON, J. VAHLNE, J. (1990) The Mechanism of Internationalization, International Marketing Review, Vol. 7 Iss 4 pp.

- JOHANSON, J.VAHLNE, J-E. (2009). The Uppsala Internationalization Process Model Revisited - From liability of foreignness to liability of outsidership. Journal of International Business Studies, Vol. 40, No. 9, pp. 1411-1431.

- JONES M., COVIELLO, N. (2005) Internationalization: Conceptualizing an Entrepreneurial Process of Behavior in Time, Journal of International Business Studies, Vol. 36, No. 3, pp. 284-303

- KALINIC, I; FORZA, C. Rapid internationalization of traditional SMEs: Between gradualist models and born globals. International Business Review ,2012

- KARRA, N; PHILLIPS, N; TRACEY, P. Building the born global firm - Developing entrepreneurial capabilities for international new venture success. Long Range Planning. 2008
- KNIGHT G., CAVUSGIL, S. (2004) Innovation, Organizational Capabilities, and the Born-Global Firm, Journal of International Business Studies, Vol. 35, No. 2, pp. 124- 142.

- KNIGHT, G; MADSEN, T; SERVAIS, P. An inquiry into bornglobal firms in Europe and the USA. International Marketing review, 2004

- KOCAK, A; ABIMBOLA, T. The effects of entrepreneurial marketing on born global performance. International Marketing Review. 2009

- KONTINEN, T, OJALA, A (2012), Internationalization pathways among family-owned SMEs International Marketing Review, vol. 29, no. 5, pp. 496-518., 10.

- LUOSTARINEN, R., GABRIELSSON, M. (2006) Globalization and marketing strategies of born globals in SMOPECs. Thunderbird International Business Review, 48(6), 773-801.

- MARCONI, M. A.; LAKATOS, E. M. Fundamentos da Metodologia Científica. 5 ed. São Paulo: Atlas, 2003.

- MORT, G.; WEERAWARDENA, J. Networking capability and international entrepreneurship - How networks function in Australian born global firms. International Marketing Review. 2006

- MORT, G. WEERAWARDENA J., LIESCH, P. (2012), Advancing entrepreneurial marketing, European Journal of Marketing, Vol. 46 Iss 3/4 pp. 542 - 561

- OVIATT, B., MCDOUGALL, P. (1994a) Toward a theory of international new ventures. Journal of International Business Studies, 25(1), 45-64.

- OVIATT, B., MCDOUGALL, P. (2005) The Internationalization of Entrepreneurship. Journal of International Business Studies, Vol. 36, No. 1, pp. 2-8.

- OVIATT, B., MCDOUgALL, P. (1997) Challenges for internationalization process theory: the case of international new ventures. Management International Review, 37, 8599.

- OVIATT, B., MCDOUGALL, P; SHANE, S. (1994b) Explaining the formation of international new ventures: The limits of theories from international business research. Journal of business venturing ,Nov 1994, Vol. 9 Issue 6, p469, 19 p.

- SEPUlVEDA, F.; GABRIELSON, M. Network development and firm growth: A resource-based study of B2B Born Globals. Industrial Marketing Management .2013

- sharma, D., BLOMSTERMO, A. (2003), The internationalization process of born globals: a network view, International business review, 12, 739-753

- SWANBORN, P., Case study research: What, Why and How? 1. ed. London: Sage, 2010.

- TAYLOR, M; JACK, R. Understanding the pace, scale and pattern of firm internationalization: An extension of the "born-global" concept. International Small Business Journal. 2013

- TEECE, D., PISANO, G. AND SHUEN, A. (1997), Dynamic Capabilities and Strategic Management. Strategic Management Journal, Vol. 18, No. 7, pp. 509-533. 
- TRUdGen, R.; FREEMAN, S. Measuring the Performance of Born-Global Firms Throughout their Development Process: The Roles of initial Market Selection and Internationalization Speed. Management International Review, 2014

- TUPpURA, A. et al. (2008) Linking knowledge, entry timing and internationalization strategy, International Business Review 17, 473-487 Vol. 43, No.5, pp. 909-924.
- Weerawardena, J., Sullivan mort, G., Liesch, P., KNIGHT, G. (2007) Conceptualizing accelerated internationalization in the born global firm: a dynamic capabilities perspective, Journal of World Business, Vol. 42 No. 3, pp. 294-306.

- Wernerfelt, B. (1984), The Resource-Based View of the Firm. Strategic Management Journal, Vol. 5, No. 2, pp. 171180.

\section{Appendix I}

\begin{tabular}{|c|c|c|c|}
\hline Author & Title & Journal & Year \\
\hline Knight, G., Cavusgil, S. & $\begin{array}{l}\text { Innovation, organizational capabilities, and } \\
\text { the born-global firm }\end{array}$ & $\begin{array}{l}\text { Journal of International Business } \\
\text { Studies }\end{array}$ & 2004 \\
\hline Chetty, S., Campbell-Hunt, C. & $\begin{array}{l}\text { A Strategic Approach to Internationalization: } \\
\text { A Traditional versus a "Born-Global" } \\
\text { Approach }\end{array}$ & Journal of International Marketing & 2004 \\
\hline $\begin{array}{l}\text { Knight, G., Madsen, T., } \\
\text { Servais, P. }\end{array}$ & $\begin{array}{l}\text { An inquiry into born-global firms in Europe } \\
\text { and the USA }\end{array}$ & International Marketing Review & 2004 \\
\hline Mort, G., Weerawardena, J. & $\begin{array}{l}\text { Networking capability and international } \\
\text { entrepreneurship - How networks function } \\
\text { in Australian born global firms }\end{array}$ & International Marketing Review & 2006 \\
\hline Freeman, S.; Cavusgil, S. & $\begin{array}{l}\text { Toward a typology of commitment states } \\
\text { among managers of born global firms: A } \\
\text { study of accelerated internationalization }\end{array}$ & Journal of International Marketing & 2007 \\
\hline $\begin{array}{l}\text { Karra, N., Phillips, N., Tracey, } \\
\text { P. }\end{array}$ & $\begin{array}{l}\text { Building the born global firm - Developing } \\
\text { entrepreneurial capabilities for } \\
\text { international new venture success }\end{array}$ & Long Range Planning & 2008 \\
\hline Kocak, A., Abimbola, T. & $\begin{array}{l}\text { The effects of entrepreneurial marketing on } \\
\text { born global performance }\end{array}$ & International Marketing Review & 2009 \\
\hline Kalinic, I., Forza, C. & $\begin{array}{l}\text { Rapid internationalization of traditional } \\
\text { SMEs: Between gradualist models and born } \\
\text { globals }\end{array}$ & International Business Review & 2012 \\
\hline $\begin{array}{l}\text { Freeman, S., Hutchings, K., } \\
\text { Chetty, S. }\end{array}$ & $\begin{array}{l}\text { Born-Globals and Culturally Proximate } \\
\text { Markets }\end{array}$ & $\begin{array}{l}\text { Management } \\
\text { Review }\end{array}$ & 2012 \\
\hline $\begin{array}{l}\text { Sepulveda, F., Gabrielsson, } \\
\text { M. }\end{array}$ & $\begin{array}{l}\text { Network development and firm growth: A } \\
\text { resource-based study of B2B Born Globals }\end{array}$ & $\begin{array}{l}\text { Industrial } \\
\text { Management }\end{array}$ & 2013 \\
\hline Taylor, M., Jack, R. & $\begin{array}{l}\text { Understanding the pace, scale and pattern } \\
\text { of firm internationalization: An extension of } \\
\text { the "born global" concept }\end{array}$ & $\begin{array}{l}\text { International Small Business } \\
\text { Journal }\end{array}$ & 2013 \\
\hline $\begin{array}{l}\text { Gabrielsson, M., Gabrielsson, } \\
\text { P. }\end{array}$ & $\begin{array}{l}\text { Internet-based sales channel strategies of } \\
\text { born global firms }\end{array}$ & International Business Review & 2011 \\
\hline $\begin{array}{l}\text { Mort, G., Weerawardena, J., } \\
\text { Liesch, P. }\end{array}$ & $\begin{array}{l}\text { Advancing entrepreneurial marketing } \\
\text { Evidence from born global firms }\end{array}$ & European Journal of Marketing & 2012 \\
\hline Hagen, B., Zucchella, A. & $\begin{array}{l}\text { Born Global or Born to Run? The Long-Term } \\
\text { Growth of Born Global Firms }\end{array}$ & $\begin{array}{l}\text { Management } \\
\text { Review }\end{array}$ & 2014 \\
\hline Trudgen, R., Freeman, S. & $\begin{array}{l}\text { Measuring the Performance of Born-Global } \\
\text { Firms Throughout Their Development } \\
\text { Process: The Roles of Initial Market Selection } \\
\text { and Internationalisation Speed }\end{array}$ & $\begin{array}{l}\text { Management } \\
\text { Review }\end{array}$ & 2014 \\
\hline Kaur, S., Sandhu, M. & $\begin{array}{l}\text { Internationalisation of born global firms: } \\
\text { Evidence from Malaysia }\end{array}$ & $\begin{array}{l}\text { Journal of The Asia Pacific } \\
\text { Economy }\end{array}$ & 2014 \\
\hline
\end{tabular}




\section{Appendix II}

\begin{tabular}{|c|c|c|c|c|c|c|c|}
\hline \multirow[t]{2}{*}{ Authors } & \multirow[t]{2}{*}{ Year } & \multirow{2}{*}{$\begin{array}{l}\text { Internal factors } \\
\text { owner/manager } \\
\text { knowledge }\end{array}$} & \multicolumn{5}{|c|}{ External factors } \\
\hline & & & $\begin{array}{l}\text { firm strategic } \\
\text { focus }\end{array}$ & $\begin{array}{l}\text { firm's innovative } \\
\text { capacity }\end{array}$ & $\begin{array}{l}\text { domestic } \\
\text { market growth }\end{array}$ & $\begin{array}{l}\text { market } \\
\text { development } \\
\text { (abroad) }\end{array}$ & $\begin{array}{l}\text { partnership, } \\
\text { networking }\end{array}$ \\
\hline $\begin{array}{l}\text { Knight, G; Cavusgil, } \\
\text { S. }\end{array}$ & 2004 & $\begin{array}{l}\text { International } \\
\text { entrepreneurial }\end{array}$ & & $\begin{array}{l}\text { Unique products } \\
\text { development, quality, } \\
\text { Global Technological } \\
\text { Competence }\end{array}$ & & & \\
\hline $\begin{array}{l}\text { Chetty, S; } \\
\text { Campbell-Hunt, C }\end{array}$ & 2004 & $\begin{array}{l}\text { capability to } \\
\text { internationalize }\end{array}$ & $\begin{array}{l}\text { influence of } \\
\text { firm strategy, } \\
\text { time to } \\
\text { internationaliza } \\
\text { tion }\end{array}$ & & $\begin{array}{l}\text { importance of } \\
\text { the home } \\
\text { market }\end{array}$ & $\begin{array}{l}\text { psychic } \\
\text { distance }\end{array}$ & use of networks \\
\hline $\begin{array}{l}\text { Knight, G; Madsen, } \\
\text { T; Servais, P }\end{array}$ & 2004 & $\begin{array}{l}\text { entrepreneur with } \\
\text { experience (intl) }\end{array}$ & & $\begin{array}{l}\text { focus on the customer } \\
\text { (portfolio and } \\
\text { marketing } \\
\text { competence) }\end{array}$ & & & \\
\hline $\begin{array}{l}\text { Mort, G.; } \\
\text { Weerawardena, J. }\end{array}$ & 2006 & & & & & & $\begin{array}{l}\text { role/value of } \\
\text { networking }\end{array}$ \\
\hline $\begin{array}{l}\text { Freeman, S.; } \\
\text { Cavusgil, S. }\end{array}$ & 2007 & $\begin{array}{l}\text { managerial } \\
\text { commitment and } \\
\text { organizational } \\
\text { characteristics }\end{array}$ & & & $\begin{array}{l}\text { Market } \\
\text { impediments } \\
\text { (saturation) }\end{array}$ & $\begin{array}{l}\text { Psychic } \\
\text { distance }\end{array}$ & $\begin{array}{l}\text { network } \\
\text { knowledge }\end{array}$ \\
\hline $\begin{array}{l}\text { Karra, N.; Phillips, } \\
\text { N.; Tracey, P. }\end{array}$ & 2008 & $\begin{array}{l}\text { entrepreneur } \\
\text { competence (identify } \\
\text { opportunities) }\end{array}$ & & & & $\begin{array}{l}\text { institutional } \\
\text { bridging }\end{array}$ & $\begin{array}{l}\text { preference and } \\
\text { capacity for } \\
\text { cross-cultural } \\
\text { collaboration }\end{array}$ \\
\hline $\begin{array}{l}\text { Kocak, A., } \\
\text { Abimbola, T. }\end{array}$ & 2009 & $\begin{array}{l}\text { entrepreneurial } \\
\text { capital, learning } \\
\text { orientation }\end{array}$ & $\begin{array}{l}\text { organizational } \\
\text { structure }\end{array}$ & innovation & & $\begin{array}{l}\text { market } \\
\text { orientations }\end{array}$ & \\
\hline Kalinic, I.; Forza, C. & 2012 & role of entrepreneur & $\begin{array}{l}\text { capability to } \\
\text { adapt the firm }\end{array}$ & $\begin{array}{l}\text { focus on the } \\
\text { important/significant } \\
\text { customer }\end{array}$ & & $\begin{array}{l}\text { market } \\
\text { knowledge }\end{array}$ & $\begin{array}{l}\text { local partners } \\
\text { and experts }\end{array}$ \\
\hline $\begin{array}{l}\text { Freeman, S.; } \\
\text { Hutchings, K.; } \\
\text { Chetty, S. }\end{array}$ & 2012 & $\begin{array}{l}\text { market as a platform } \\
\text { to additional markets } \\
\text {, experience (intl) }\end{array}$ & & $\begin{array}{l}\text { historic links with } \\
\text { clients }\end{array}$ & $\begin{array}{l}\text { downturns/ } \\
\text { regulatory } \\
\text { environment in } \\
\text { the home } \\
\text { market }\end{array}$ & $\begin{array}{l}\text { familiarity with } \\
\text { the culture and } \\
\text { language }\end{array}$ & $\begin{array}{l}\text { born-globals } \\
\text { have } \\
\text { associations } \\
\text { with other } \\
\text { business entities }\end{array}$ \\
\hline $\begin{array}{l}\text { Sepulveda, F.; } \\
\text { Gabrielsson, M. }\end{array}$ & 2013 & & & $\begin{array}{l}\text { knowledge \& product } \\
\text { capabilities }\end{array}$ & & $\begin{array}{l}\text { market } \\
\text { knowledge }\end{array}$ & $\begin{array}{l}\text { network } \\
\text { management } \\
\text { from inception }\end{array}$ \\
\hline Taylor, M.; Jack, R. & 2013 & entrepreneurial drive & & innovative culture & $\begin{array}{l}\text { small and } \\
\text { mature } \\
\text { domestic } \\
\text { market }\end{array}$ & $\begin{array}{l}\text { cultural } \\
\text { similarity with } \\
\text { the market }\end{array}$ & \\
\hline $\begin{array}{l}\text { Gabrielsson, M; } \\
\text { Gabrielsson, P. }\end{array}$ & 2011 & & & & & & $\begin{array}{l}\text { relationship, } \\
\text { partnership } \\
\text { advantages }\end{array}$ \\
\hline $\begin{array}{l}\text { Mort, } \\
\text { G.Weerawardena, } \\
\text { J., Liesch, P. }\end{array}$ & 2012 & opportunity creation & $\begin{array}{l}\text { Resource } \\
\text { enhancement }\end{array}$ & $\begin{array}{l}\text { innovative products, } \\
\text { customer intimacy }\end{array}$ & $\begin{array}{l}\text { legitimacy } \\
\text { stablishment }\end{array}$ & & \\
\hline $\begin{array}{l}\text { Hagen, B.; } \\
\text { Zucchella, A. }\end{array}$ & 2014 & $\begin{array}{l}\text { entrepreneurial } \\
\text { capabilities and } \\
\text { characteristics }\end{array}$ & & & environment & & $\begin{array}{l}\text { networks and } \\
\text { partnerships }\end{array}$ \\
\hline $\begin{array}{l}\text { Trudgen, R.; } \\
\text { Freeman, S. }\end{array}$ & 2014 & & & $\begin{array}{l}\text { unique and innovative } \\
\text { products }\end{array}$ & & $\begin{array}{l}\text { psychic } \\
\text { distance }\end{array}$ & \\
\hline $\begin{array}{l}\text { Kaur, S., Sandhu, } \\
\text { M. }\end{array}$ & 2014 & $\begin{array}{l}\text { Background of the } \\
\text { founders/managers } \\
\text { (prior experience), } \\
\text { entrepreneurial } \\
\text { orientation }\end{array}$ & Firm resources & & $\begin{array}{l}\text { Market/industr } \\
\text { y structure } \\
\text { limitation, } \\
\text { Governmental } \\
\text { support }\end{array}$ & $\begin{array}{l}\text { Globalisation } \\
\text { forces }\end{array}$ & Networking \\
\hline
\end{tabular}




\section{Appendix III}

\section{Interview conducted in $\mathbf{0 6 . 2 0 . 2 0 1 5}$ by the researches - selection}

Interviewer
When you start to consult a start-up. do they usually
have their own initiatives to go abroad directly, or is
their focus on securing the home market for a few
years. And start thinking about other markets
depending on the outcome/performance of the first
years?
I see, so we can say that usually we have a very
"organic" growth process. When the market becomes
too small the companies start looking for new
opportunities abroad.

Can you give an appraisal of how strong the market knowledge of those start-ups are before they enter a market? Is it rather almost perfectly prepared or is it rather an incremental process, in the sense that a company begins exporting in small quantities for a rather long period and once they think they understood the market, which they focus strongly on it.

Interviewee: CEO and founder of a consulting company

It depends very much on market where the start-up is founded.

It depends on the home market, whether start-ups think globally or if they prefer grow naturally at home, and after reaching a certain volume, what how they can grow further.

Yes, but also considering the other possible scenarios and cases.

It depends on the nature of the business. When you have a mobile app, it will scale itself automatically. Also because of the global infrastructure. Then again there are the regionally focused models.

But generally there is some preparation. When considering Europe, which is a large market, but also divided in 30ish countries, with particular tax system, regulations. You need to hire someone fixedly, if he isn't a freelancer, with then other tax status. When you want to go abroad and need to be prepared accordingly. The second aspect is the market entry. Again depending on the business model depending on the target customers that you want to reach out to. Some ideas spread automatically, the companies just need to deliver the infrastructure. However, every country has its individual specialties, which are necessary to know for a company before the market entry. Each company has its own way to do it. or do they feel very confident and with a lot of knowledge before starting the process

So there are again primarily external factors on which the company needs to adapt to.

When a company decides to go abroad, how do companies internationalize, which steps do they take? Can you give examples? Do they start with sales assistance, distributors, acquire staff there?

Not always. The external factors are very important to find out whether an escalation and the costs of a market entry are. Internal factors, like a lack of personnel, or immature cost structures, no resources need to be observed in combination.

Our professional services firm, are very dependent on the local market. We have a big network here in London and have a brand equity. If we wanted to go to, let's say São Paulo, I would not know anyone. And people would not know us. Therefore, we'd have to build the local structures again. In our case we would go to business schools, do some speeches/events, and invite some PR agencies in order to attract attention. But that takes at least a year, until you can gain a sufficient amount of clients. We would have to imitate the business environment that we created in London to the other city. That depends a lot on people and relationships. You cannot outsource that. Our clients could get advising somewhere else, but they also pay for the relationship, trust that we gained. So it is hard to replicate for us. Having a shop or restaurant would be easier. They come for your product. You can also source the supplier and distributors locally. But in this case you still need to take care of the cultural differences. You need to adjust your product accordingly. Many companies look for local supplier which are usually cheaper. Very important are local investors. They do know the local environment and not only bring money, but also the social capital. This might be one of the most important factors.

\begin{abstract}
The investors?
Would you set goals for your foreign operations which are in relation to your home market? For example that you want to achieve a certain foreign percentage after a few years. Or do you just set usual growth objectives, without relating it to the home market.
\end{abstract}

So there is not the idea of making sure the foreign presence is high and that the international involvement takes a strong part of the overall companies focus/expenses? Is really is just about the individual markets and what is achievable there.

Does he to the research on his own and flies there, talks to investors, BCs or does he acquire someone from that market

Are there characteristics of founders or CEOs of startups where you would say that they are missing some
Local Investors

The goal setting is dependent on the environment. Especially depending on the market size. The goals are usually set in market share, but also with regards to the then resulting volume. You will not be able to achieve your goals perfectly. It usually is a proportional process. Secondly, goals don't always have to be in turnover or volume, but can also be measured in market domination.

Decisions are made rationally and therefore there is just an evaluation of costs vs. gains. What is the ROI or the long run profit expectations? It seems more a political, or lobby thing which try to reach a big level of publicity, or those non-material goals. In the business world especially start-ups, are to strong bound to and let by economical restrictions and thoughts.

The research itself is usually done from home by several market analyses available from other companies. Or especially business schools have access to other market analysis institutes. With those data the segmentation of the market is started. Top to bottom analysis at first. Market volumes, total accessible market and various other indicators are used in order to achieve a profound decision

You can take a look at HBR, it is about "global dexterity". They say that the capability to adapt to other markets and/or cultures, but without leaving the own comfort zone. It's about still 
characteristics which are necessary to establish the company in a foreign market? Do they lack the knowledge, the cultural sensitivity?

Have you ever experienced that you told someone that he doesn't fit to go abroad. being yourself while adapting other manners both on personal and business level. This is a very important attribute. But it is also important to understand the dynamics of markets.

It is just their duty to inform themselves about the no-go's of a country and do their research. But there is always the possibility to learn from the differences and to find solutions according, also regarding to the punctuality.

Especially start-ups in their first 2 or 3 years have very little resources, therefore those company think twice or three times how to spend the money. The first priority usually is human capital. And once you decide to go abroad, those companies start looking for investors. When you do not yet have a significant volume you need to firstly take care of the shorter term cost consequences. But also other trains of thoughts are important. For a London fashion start up, it makes no sense to go to Pakistan. Although there are many young people, the total addressable market is bigger, the culture just doesn't fit. Especially on business schools you always learn a rational, commercial view on also cultural aspects.

For me it would not make sense to risk the achievements you have already earned in the home market. Furthermore, one must think of the internal structures and processes which need to be established. You need a functioning HR, sales, accounting. Those structures itself are already a big challenge in order to have it working fluently. Those who are neglecting those processes or don't have it $100 \%$ up and running in the home market, will never be able to do that in a foreign market. You need to have learned it first

Some articles wrote that the flexible structures are an advantage to adapt to foreign markets.

Local resources are always necessary to be successful in that market. The business mode usually is similar; it just gets slightly adapted to the other country. So if companies go abroad, the business model goes abroad, not the people. The old business model with new and different people, which is internationalization.

Considering the resources necessary, it is a big step for the companies.
Yes, but you might also consider the personnel costs. So you also save a lot of money in comparison to western countries. Going to emerging markets lets you get financial advantages of the step. But the initial initiative need to be financed from the home-country

\section{About the authors}

- Ananda Carvalho Pimenta, PhD candidate in Business at FEA-USP; earned a master's degree in Business at PUC SP (2014); and a bachelor's degree in Business Administration at FEA - USP (1997). Also holds a post-graduate degree in Marketing and an MBA in Finance at FGV (2003 and 2010). E-mail: ananda.pimenta@usp.br

- Marcus Joswig, Master's Student in Engineering and Business Administration at TU Darmstadt Postgraduation Exchange Semester at FEA - USP (2015) Bachelor's Degree in Engineering and Business Administration at TU Darmstadt. E-mail: marcusjoswig@gmail.com

- Moacir de Miranda Oliveira Junior, Full Professor of the Business Administration Department at FEAUSP. He holds a PhD (2000) and a Master's degree (1994) in Administration at University of São Paulo. He graduated in Business Administration at University of Pernambuco (1989). He is currently Deputy Head of the Department of Business Administration and Coordinator of PPGA - Graduate Program in Administration (MSc and PhD Academic) of FEA-USP. He is a Research Productivity Scholar at CNPq. He is the Chief Editor of RAl - Innovation and Management Review since 2015. E-mail: mirandaoliveira@usp.br

- Roberto Sbragia, He holds a PhD degree in Business Administration at University of São Paulo (1982), a Master's degree in Business Administration at University of São Paulo (1977) and a undergraduate degree in Administration at University of São Paulo (1974). Postdoctoral degree in Management of $R \& D$ at Northwestern University / Technological Institute / Department of Industrial Engineering and Management Sciences. He is currently a professor at the University of São Paulo, working within the Business Administration Department of the Faculdade de Economia, Administração e Contabilidade - 
FEA-USP, where he participates in the group of studies in Innovation Management and Technological Projects. He currently works on the following line researches: innovation, evaluation, industry, management of technological innovation and project management.E-mail: rsbragia@usp.br

\title{
Dimensões dos estudos de caso de empresas born-globals
}

Ananda Carvalho PimentaA, Marcus Joswig ${ }^{\mathrm{B}}$, Moacir de Miranda Oliveira Junior ${ }^{A}$, Roberto Sbragia ${ }^{A}$

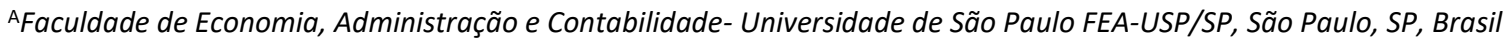 \\ ${ }^{\mathrm{B}}$ Fachbereich Rechts-und Wirtschaftswissenschaften - Technische Universität Darmstadt, \\ FB1/TU Darmstadt, Darmstadt/Hessen, Alemanha
}

\section{DETALHES DO ARTIGO}

\section{Histórico do artigo:}

Recebido em 2 de Outubro de 2015

Aceito em 20 de Janeiro de 2017

Disponível online em 30 de Abril de 2017

Sistema de revisão "Double Blind Review"

Editor científico

Ilan Avrichir

\section{Palavras-chave:}

Born-global

Estudo de caso

Conceitos

\begin{abstract}
RESUMO
O objetivo desta pesquisa é analisar quais são as dimensões e atributos discutidos em estudos de caso de empresas born-globals, apresentados na literatura e na prática. Para estes dois objetivos específicos, foram propostos: i) identificar as dimensões utilizadas para estudar as empresas born-globals; ii) identificar os principais conceitos aplicados a essas dimensões. Ambas as análises são baseadas em estudos de caso abordados na literatura e em estudos de caso práticos. Esta pesquisa é classificada como exploratória e contém uma análise de conteúdo. Além disso, baseou-se em uma seleção de artigos acadêmicos obtidos no banco de dados ISI Web of Knowledge, com foco em estudos de caso de empresas born-globals. Os resultados demonstram que as principais questões relativas às empresas born-globals são encontradas em uma perspectiva alinhada com a teoria, mesmo quando o artigo é focado em uma determinada indústria. Como contribuição, este estudo apresentou a lista de dimensões e atributos que podem ser utilizados como referência para discussões complementares sobre os estudos de caso born-globals ou mesmo proposições teóricas. A composição dos estudos de caso, que fornece uma visão geral para os pesquisadores, pode ser considerada como uma contribuição adicional deste artigo.
\end{abstract}

(C) 2017 Internext | ESPM. Todos os direitos reservados.

To cite this article:

Pimenta, A. C., Joswig, M., de Miranda Oliveira Junior, M., Sbragia, R. (2017). Dimensions on born-global firms' case studies. Internext - Revista Eletrônica de Negócios Internacionais, 12 (1), 48-61. DOI: 10.18568/1980-4865.12148-61

To access this article: $h t t p: / / d x . d o i . o r g / 10.18568 / 1980-4865.12148-61$ 